in vivo $35: 1409-1417$ (2021)

doi:10.21873/invivo.12393

Review

\title{
Coronavirus Disease 2019 and Nasal Conditions: A Review of Current Evidence
}

\author{
ISAO SUZAKI and HITOME KOBAYASHI \\ Department of Otorhinolaryngology, School of Medicine, Showa University, Tokyo, Japan
}

\begin{abstract}
The nasal epithelium expressing enriched angiotensin-converting enzyme II (ACE2), the key cell entry receptor of severe acute respiratory syndrome coronavirus 2 (SARS-CoV-2), could serve as the first barrier to protect the airway from viral infection. Recent studies have demonstrated that higher viral loads were detected in the nasal cavity than the pharynx in coronavirus disease 2019 (COVID-19) patients, and otolaryngologists should carefully consider infection prevention in clinical practice for the treatment of nasal conditions. Moreover, several studies have indicated that anosmia is one of the clinical characteristics of COVID-19, but the precise prevalence and mechanism remain unclear. Thus far, comorbidity of allergic rhinitis and chronic rhinosinusitis do not seem to be a major risk factor for severe COVID-19. However, we should develop strategies in clinical practice for the treatment of nasal diseases during the pandemic. In this article, we reviewed current evidence of the relationship between COVID-19 and nasal conditions, such as COVID-19-related olfactory dysfunction, allergic rhinitis, and chronic rhinosinusitis.
\end{abstract}

Severe acute respiratory syndrome coronavirus 2 (SARSCoV-2) was identified as the pathogen of pneumonia of unknown etiology that was discovered in December 2019 in Wuhan, China (1). It is classified as a beta coronavirus along with severe acute respiratory syndrome coronavirus (SARS$\mathrm{CoV}$ ) and Middle East respiratory syndrome (MERS)-CoV. The disease caused by SARS-CoV-2 infection was named coronavirus disease 2019 (COVID-19) by the World Health

This article is freely accessible online.

Correspondence to: Isao Suzaki, MD, Ph.D, 1-5-8 Hatanodai, Shinagawa-ku, Tokyo, 142-8666, Japan. Tel: +81 337848563, Fax: +81 337840981, e-mail: i-suzaki@med.showa-u.ac.jp

Key Words: SARS-CoV-2, COVID-19, olfactory dysfunction, ACE2, rhinitis, review.
Organization (WHO) (2). COVID-19 has rapidly spread all over the world with over 92.5 million cases and has killed more than 2.0 million people worldwide as of January 2021.

The pandemic of COVID-19 has greatly impacted several aspects of the clinical field of otolaryngology, including infection prevention and patient management of both inpatients and outpatients. It has been confirmed that risk factors impacting the severity of COVID-19 included comorbidity of malignant tumors, chronic obstructive pulmonary disease, chronic kidney disease, liver disease, obesity, hyperlipidemia, hypertension, type 2 diabetes, and immunosuppression after transplantation of organs, as well as older age and smoking, compared to healthy persons (311). We should also consider comorbidity of HIV, pregnancy, and continued use of systemic corticosteroids or biological disease-modifying antirheumatic drugs (bDMARDs) targeting inflammatory mediators including tumor necrosis factor (TNF) and IL-6 (12-15). However, knowledge about the relationship between SARS-CoV-2 infection and upper airway disease remains limited. Nasal conditions, including allergic rhinitis and chronic rhinosinusitis (CRS), are highly prevalent worldwide, affecting up to $40 \%$ of the population (16). Otolaryngologists should know and update the characteristics and countermeasures of COVID-19, because airway passages of the nasal cavity and nasopharynx are two of the main pathways of viral infection, including SARS$\mathrm{CoV}-2$. In this review, we summarized previous reports and knowledge on the relationship between COVID-19 and nasal conditions, including COVID-19-related anosmia, allergic rhinitis, and CRS.

\section{The Nasal Cavity and SARS-Cov-2}

It is reported that two human host factors have a crucial role in SARS-CoV-2 infection. For viral entry to human cells, spike (S) protein expressed on the surface of SARS-Cov-2 binds to the angiotensin-converting enzyme II (ACE2) receptor, like in SARS-CoV (17). Transmembrane serine protease serine 2 (TMPRSS2) cleaves and activates the S protein of SARS-CoV- 
2 to allow virus-cell fusion (18). In other words, ACE2 is the receptor-binding domain of SARS-CoV-2, and it is essential for docking to the S protein of SARS-CoV-2, while TMPRSS2 is essential to cleave to the docked $S$ protein for virus entry into the cell by membrane fusion (Figure 1). It has been revealed that the antibody blocking these signals of entry could prevent viral infection in vitro and that antibody is expected to be a therapeutic agent candidate $(18,19)$. It is also identified that the antiparasitic compound ivermectin could interfere with the attachment of the spike to the cell membrane and the several clinical trials to determine the efficacy of ivermectin on COVID-19 are still undergoing (20). ACE2 and TMPRSS2 expression have been detected in both nasal and lung tissue in humans by immunohistochemistry (21). Specifically, human nasal epithelial cells showed the highest ACE2 expression among all investigated cells in the upper and lower airway tract (22). Ziegler et al. revealed that ACE2 expression was increased by the stimulation of interferons (IFNs) and influenza viral infection in human nasal epithelial cells (23). It was demonstrated that IL-13, key cytokines of type 2 inflammation, reduced ACE2 expression in air-liquid-interface cultured nasal cells collected from asthmatic children by brushing (24). Smith et al. revealed that cigarette smoke exposure dose-dependently increased ACE2 expression in lung tissue (25). The regulation of ACE2 expression was also associated with various other factors, such as obesity, gender, and comorbidity of chronic diseases including allergic diseases (26). These findings could be related to the difference between individuals in susceptibility to SARS-CoV-2 infection or severity of COVID19. Besides being the receptor of SARS-CoV-2, ACE2 has been identified as a tissue-protective peptide to prevent vasoconstriction, fibroproliferation, and apoptosis of epithelial cells and expression of inflammatory mediators by regulating the change of angiotensin (Ang) II to Ang 1-7 in the lungs (2729). However, the precise role of ACE2 in nasal diseases has not yet been elucidated.

The nasal cavity serves as the first barrier to protect the lower airway tract from allergens and pathogens such as bacteria and viruses. Higher viral loads were detected in the nose than in the throat from swabs collected from patients with COVID-19 soon after onset of symptoms (30). These findings may suggest that the nasal cavity expresses enriched receptors of virus and contains high viral load, and it is an important organ for SARS-CoV-2 entry and COVID-19 development. Therefore, we should be familiar with countermeasures for clinical management of rhinology during the pandemic.

\section{Olfactory Dysfunction in COVID-19}

Early common symptoms of COVID-19 are fever, cough, fatigue, and shortness of breath, which are like influenza and cold symptoms. Therefore, it seems difficult to clearly

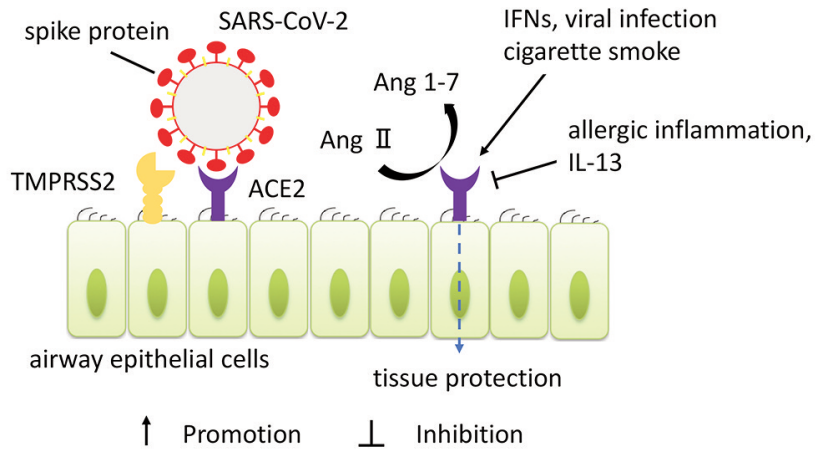

Figure 1. Expression of angiotensin-converting enzyme II (ACE2) receptor in human airway epithelium and role of ACE2. Severe acute respiratory syndrome coronavirus 2 (SARS-CoV-2) binds to ACE2 expressed as receptor on human airway epithelial cells, and the serine protease transmembrane serine protease serine 2 (TMPRSS2) cleaves and activates the spike protein to allow virus-cell fusion and cell entry. ACE2 also has a protective effect on airway tissue by inactivating Ang II and producing Ang 1-7. The expression of ACE2 is modulated by various factors, such as interferons (IFNs), viral infection, smoking, and type 2 inflammation.

distinguish those diseases and COVID-19 during the epidemic season. However, it is notable that some patients with COVID-19 show olfactory dysfunction (anosmia or dysosmia) and dysgeusia, so these may be significant clinical features of COVID-19. According to previous reports, clinical features of olfactory dysfunction related to COVID19 have the following features: (1) acute onset without any triggers, (2) severity of anosmia or severe disability, (3) not accompanied by other nasal symptoms such as nasal obstruction and rhinorrhea, and (4) resolving in the relative short term (Table I) (31-33).

Lechien et al. reported that 357 of 417 (85.6\%) European mild-to-moderate COVID-19 cases had olfactory-related symptoms related to the infection (34). Alternatively, olfactory dysfunction was reported in only $5.1 \%$ of 214 cases in China (35). According to a meta-analysis, the prevalence of olfactory dysfunction is estimated to be $38.5 \%$ in patients with COVID-19. It is most likely not associated with age but with disease severity and race. Compared to the East Asian population, the prevalence of olfactory dysfunction in individuals of Caucasian descent is reported to be approximately threefold higher. The authors speculated that this result could be due to SARS-CoV-2 mutation and ethnic differences in host factors, including virus receptor, but further investigations are required (35). Although the actual frequency of olfactory dysfunction in patients with COVID19 remains unknown, these results could be due to differences in research methods, such as subjective or objective evaluation of olfactory function. In another study, an online survey used a self-reported questionnaire about loss of smell 
Table I. Representative articles on the relationship between COVID-19 and nasal diseases.

\begin{tabular}{|c|c|c|c|c|}
\hline Nasal disease & Title & Authors & Year & Reference \\
\hline \multirow{3}{*}{$\begin{array}{l}\text { Olfactory } \\
\text { dysfunction }\end{array}$} & Anosmia and ageusia: Common findings in COVID-19 patients & Vaira et al. & 2020 & 31 \\
\hline & $\begin{array}{l}\text { Olfactory and gustatory dysfunctions as a clinical presentation } \\
\text { of mild-to-moderate forms of the coronavirus disease } \\
\text { (COVID-19): A multicenter European study }\end{array}$ & Lechien et al. & 2020 & 34 \\
\hline & $\begin{array}{l}\text { Expression of the SARS-CoV-2 entry proteins, ACE2 and TMPRSS2, } \\
\text { in cells of the olfactory epithelium: Identification of cell types and trends with age }\end{array}$ & Bilinska et al. & 2020 & 40 \\
\hline \multirow[t]{4}{*}{$\begin{array}{c}\text { Allergic } \\
\text { rhinitis }\end{array}$} & $\begin{array}{l}\text { COVID-19 pandemic: Practical considerations on the organization of an allergy clinic- } \\
\text { An EAACI/ARIA position paper }\end{array}$ & Pfaar et al. & 2021 & 43 \\
\hline & Type 2 inflammation modulates ACE2 and TMPRSS2 in airway epithelial cells & Kimura et al. & 2020 & 44 \\
\hline & $\begin{array}{l}\text { Intranasal corticosteroids in allergic rhinitis in COVID-19 infected patients: } \\
\text { An ARIA-EAACI statement }\end{array}$ & Bousquet et al. & 2020 & 47 \\
\hline & $\begin{array}{l}\text { Handling of allergen immunotherapy in the COVID-19 pandemic: } \\
\text { An ARIA-EAACI statement }\end{array}$ & Pfaar et al. & 2020 & 48 \\
\hline \multirow[t]{2}{*}{$\begin{array}{l}\text { Chronic } \\
\text { rhinosinusitis }\end{array}$} & $\begin{array}{l}\text { Prevalence and characterization of asthma in hospitalized } \\
\text { and nonhospitalized patients with COVID-19 }\end{array}$ & Chhiba et al. & 2020 & 53 \\
\hline & $\begin{array}{l}\text { Implication for COVID-19 risk and disease management } \\
\text { in patients with chronic inflammatory respiratory diseases }\end{array}$ & Yao et al. & 2020 & 54 \\
\hline
\end{tabular}

in 382 patients with COVID-19. Results suggested that $86.4 \%$ reported complete loss of smell when first surveyed, but $11.5 \%$ reported complete recovery, and $80.1 \%$ reported partial recovery of loss of smell 1 week after the first survey (36). It has also been reported that approximately $63 \%$ of patients with COVID-19 who complained for loss of smell reported partial or complete improvement in the first 30 days after onset (37). As shown in these clinical studies, olfactory function in COVID-19 seems to be relatively recoverable. However, some patients show a prolonged or permanent disability of smell, and the precise probability and degree of this type of dysfunction are unknown.

Eliezer et al. reported that radiological images of patients with COVID-19-related anosmia showed bilateral inflammatory obstruction of the olfactory clefts, and no significant abnormal findings were detected in other parts of the nasal cavities, paranasal sinuses, and intracranial areas including the olfactory bulbs (38). It has been recently reported that ACE2 and TMPRSS2 gene expression and protein were confirmed in the olfactory epithelium but were strongly expressed in sustentacular cells surrounding the neuron rather than in olfactory sensory neuron $(39,40)$. In vivo, Bryche et al. revealed that isolated nasal invasion of SARS-CoV-2 induced extensive damage in sustentacular cells in the olfactory epithelium but not in olfactory sensory neuron in a hamster model. In addition, it was also reported that the damaged olfactory epithelium induced by SARSCoV-2 infection was partially restored at 14 days postinfection (41). Thus far, it has been speculated that the mechanism of olfactory dysfunction in COVID-19 was not caused by olfactory sensory damage but by sustentacular cell damage. This speculation could support the phenomenon of prompt recovery of normal function and the clinical feature that patients do not usually complain of other nasal symptoms such as nasal obstruction and rhinorrhea.

\section{COVID-19 and Allergic Rhinitis}

Allergic rhinitis is a type I allergic disease, characterized by sneezing, rhinorrhea, and nasal obstruction. Besides these main symptoms, allergic responses in the upper and lower airway may cause various symptoms, such as headache, fatigue, anosmia, discomfort in the throat, and cough. Approximately $80 \%$ of patients with COVID-19 experience a mild clinical course that is similar to a common cold in clinical presentation, and they recover without any specific treatment (42). It could sometimes be difficult to clearly distinguish mild acute respiratory airway infectious diseases (including COVID-19 and influenza) from allergic rhinitis based only on clinical symptoms, because these conditions share many symptoms (Figure 2). To make a precise diagnosis of allergic rhinitis, physicians should combine clinical history, serum $\operatorname{IgE}$ antibody measurement, skin reaction test, nasal eosinophil staining of the nasal secretion, and nasal mucosa provocation test (16). However, the European Academy of Allergy and Clinical Immunology (EAACI) and the Allergic Rhinitis and its Impact on Asthma (ARIA) initiative produced a position paper proposing that these aerosol-generating procedures, as high-risk procedures (including nasal cytology and nasal provocation test), should be avoided and rescheduled during the COVID-19 pandemic (Table I) (43).

There is limited knowledge about the relationship between susceptibility to SARS-CoV-2 infection, the risk of severe 


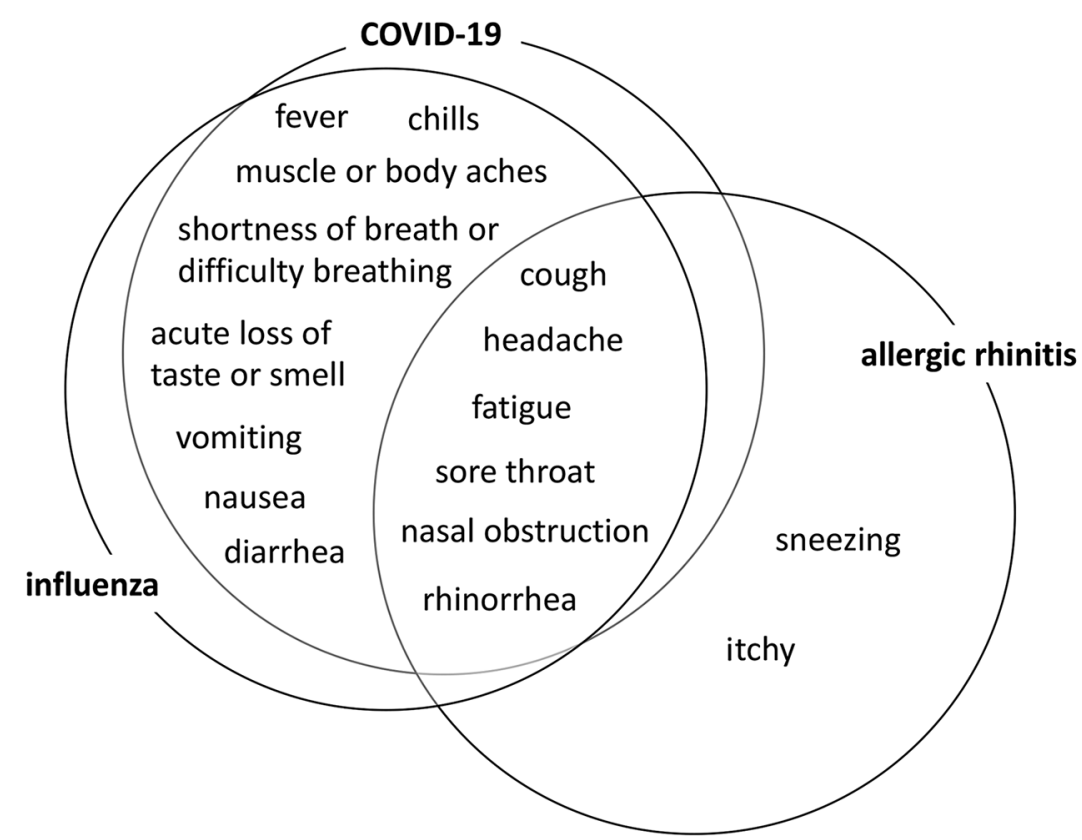

Figure 2. Common symptoms of COVID-19, influenza, and allergic rhinitis and their relationships to each other COVID-19, influenza, and allergic rhinitis share many common symptoms.

COVID-19 development, and allergic rhinitis. It has been demonstrated that expression of ACE2, the receptor of SARS-CoV-2, in nasal epithelial cells is lower in patients with allergic rhinitis and asthma than in healthy individuals (44). Reduced ACE2 expression in nasal brushing samples following an allergen challenge in patients with allergic rhinitis was also reported. In contrast, TMPRSS2, the serine protease activating $S$ protein of SARS-CoV-2, is upregulated by interleukine-13, a type 2 cytokine that is one of the key effectors of allergic diseases (45). In a report from China, it has been demonstrated that comorbidity of allergic rhinitis and asthma were not risk factors for SARS-CoV-2 infection in 140 hospitalized adult patients (46). Interestingly, ACE2 and TMPRSS2 expression is modulated by type 2 cytokines, but there is no concrete evidence thus far that allergic rhinitis modifies susceptibility to SARSCoV-2 infection or severity of COVID-19.

The pharmacotherapy of allergic rhinitis mainly consists of chemical mediator receptor antagonists such as secondgeneration $\mathrm{H}_{1}$-antihistamines and intranasal corticosteroids (INS). The EAACI/ARIA position paper proposed continued use of antihistamines and INS for therapy of allergic rhinitis in both non-infected patients and those diagnosed with COVID-19. In an approved dose, INS did not increase susceptibility to SARS-CoV-2 infection or the severity of COVID-19 (43, 47). Therefore, it is recommended that patients with allergic rhinitis continue to use antihistamines and INS to manage their symptoms.
Controlling symptoms of allergic rhinitis, such as sneezing and rhinorrhea, could contribute to prevention of SARSCoV-2 infection from the aspect of reducing aerosolgenerating events.

Allergen immunotherapy (AIT) is the only diseasemodifying therapy that confers long-term benefit on allergic rhinitis when given by subcutaneous (SCIT) or sublingual (SLIT) administration. The EAACI/ARIA position paper also proposed that special consideration should be applied for the management of AIT during the COVID-19 pandemic. For patients treated by SLIT administration, telemedicine could be a valuable option to reduce the chance of contact with other patients. Especially, it is a useful way to check a patient's status and maintain their adherence for patients treated by SLIT, since it is self-administered at home during the maintenance phase. For patients treated by SCIT administration, it is proposed that the possibility of lengthening the injection interval in the continuation phase during the pandemic be considered, although it is recommended to continue SCIT therapy to control allergic status. If patients are diagnosed with COVID-19 or suspected of SARS-CoV-2 infection, AIT should be stopped until the resolution of the disease $(43,48)$.

Omalizumab, a humanized anti-IgE antibody, was approved in 2019 as add-on therapy for severe cases of Japanese cedar pollinosis. According to the adequate usage guideline, we usually provide omalizumab as add-on therapy in addition to chemical mediator receptor antagonist and INS 
in the short term for severe Japanese cedar pollinosis, although it is administered for refractory allergic asthma and urticaria throughout the year (49). There is no evidence about the incidence of SARS-CoV-2 infection or impact on COVID-19 severity in patients with allergic rhinitis receiving omalizumab therapy. Physicians should use their appropriate clinical judgment for biologics therapy for allergic rhinitis, depending on a patient's status.

\section{COVID-19 and CRS}

CRS is defined as a condition that shows prolonged chronic inflammation in the paranasal sinuses for more than 12 weeks. The pathophysiology of CRS is heterogeneous, and various endotypes have been demonstrated, showing their inflammation patterns including type 2 inflammation dominant, non-type 2 inflammation dominant, or mixed type (50). In Japan, the diagnostic criteria for eosinophilic CRS (ECRS) as refractory CRS were established according to the multicenter large-scale epidemiological study called the "Japanese Epidemiological Survey of Refractory Eosinophilic Chronic Rhinosinusitis Study" (JESREC Study) (51). It has been reported that type 2 inflammation has an important role in the pathophysiology of ECRS and non-eosinophilic CRS shows non-type 2 inflammation, such as neutrophil dominant (52). Frequently occurring symptoms of ECRS are nasal discharge, nasal blockage, post-nasal drip, and loss of smell. The mechanism of the olfactory dysfunction in ECRS had been considered a combined impairment, with sensory dysfunction in olfactory nerves and obstructed olfactory clefts. Compared to COVID-19, the clinical history of loss of smell in ECRS involves chronic onset and frequently co-occurring nasal obstruction and rhinorrhea.

Although ACE2 receptor and TMPRSS2 expression in nasal epithelial cells seem to be modulated by type 2 inflammation, it is unknown whether they are up-regulated or down-regulated in patients with CRS who show a heterogeneous inflammation background. Chhiba et al. reported that comorbidity of rhinosinusitis in patients with COVID-19 was associated with a significantly lower risk of hospitalization compared to the absence of rhinosinusitis (Table I) (53). However, they did not define rhinosinusitis as chronic and acute, and they also considered the endotype background in their study. CRS does not appear to be a major risk for COVID-19; however, its actual risk may depend on phenotype and/or endotype. Thus far, there is limited evidence of a relationship between CRS and COVID-19.

We should consider infection prevention measures when we proceed with nasal endoscopy and tissue biopsy to diagnose and evaluate the nasal cavity findings of CRS. During the pandemic, it had been proposed that we should avoid or reschedule high-risk procedures such as aerosolgenerating events and should wear full-body personal protective equipment (PPE) if we proceed and cannot rule out the possibility of COVID-19 (43).

For CRS treatment, we usually perform combined pharmacotherapy including antibiotic therapy, INS, and short-term systemic corticosteroids (SCS), as well as biologics targeting type 2 inflammations, and endoscopic sinus surgery (ESS). Several organizations have proposed that it is important to continue to prescribe long-term control medications including topical corticosteroids, SCS, and biologics to maintain good management for patients with chronic airway inflammatory diseases (43, 54). The Global Initiative for Asthma (GINA) suggests that prescribed inhaled corticosteroids and the lowest possible dose of SCS should be continued to prevent a potential risk of exacerbation in patients with severe asthma (55). There are no sufficient data that biologics targeting type 2 inflammation (including dupilumab) increase the risk of SARS-CoV-2 infection or severity of COVID-19. The American Academy of Allergy Asthma \& Immunology suggests that patients with asthma continue to use biologics to control their symptoms during the pandemic. Physicians should judge and reevaluate need and prescribe the lowest dose of SCS to manage symptoms, and biologics therapy should be continued for refractory cases that qualify for them to limit the need for SCS as much as possible.

We should consider rescheduling operations for stand-by cases, and preoperatively screen for COVID-19, because ESS is a high-risk procedure that generates aerosols. If we cannot rule out the possibility of SARS-CoV-2 infection, we should use appropriate full-body PPE, including masks, eye protectors, and gowns during surgery.

\section{Conclusion}

Although there have been some previous reports focusing on the relationship between COVID-19 and nasal conditions, this report summarizes the current guidance and proposals for medical management of nasal diseases and conditions during the pandemic. The nasal cavity shows high viral load and high levels of ACE2 receptor expression. It has an important role in the spread of SARS-CoV-2 infection, and otolaryngologists should pay attention to infection prevention in clinical situations with nasal conditions and diseases. The mechanism of COVID-19-related olfactory dysfunction is thought to be damage of sustentacular cells expressing ACE2 receptor rather than damage of olfactory sensory neuron, but further investigations are needed. For the treatment of nasal conditions during the pandemic, we should choose the appropriate treatment to maintain adequate control of symptoms, considering potential influence on SARS-CoV-2 infection and the severity of COVID-19. Patients should be motivated to notify their healthcare 
provider in case of exacerbation or changes in their usual symptoms to maintain their quality of life, although nasal conditions such as allergic rhinitis and CRS do not appear to be high risk for COVID-19.

\section{Conflicts of Interest}

The Authors declare no conflicts of interest in association with the present study.

\section{Authors' Contributions}

I.S. collected data and prepared the article. H.K. revised it critically for important intellectual content. All Authors approved the final version.

\section{References}

1 Zhu N, Zhang D, Wang W, Li X, Yang B, Song J, Zhao X, Huang B, Shi W, Lu R, Niu P, Zhan F, Ma X, Wang D, Xu W, Wu G, Gao GF, Tan $\mathrm{W}$ and China Novel Coronavirus Investigating and Research Team: A novel coronavirus from patients with pneumonia in China, 2019. N Engl J Med 382(8): 727-733, 2020. PMID: 31978945. DOI: 10.1056/ NEJMoa2001017

2 World Health Organization: Naming the coronavirus disease (COVID-19) and the virus that causes it. Available at: https://www.who.int/emergencies/diseases/novel-coronavirus2019/technical-guidance/naming-the-coronavirus-disease-(covid2019)-and-the-virus-that-causes-it [Last accessed on March 23, 2021]

3 Matsunaga N, Hayakawa K, Terada M, Ohtsu H, Asai Y, Tsuzuki S, Suzuki S, Toyoda A, Suzuki K, Endo M, Fujii N, Suzuki M, Saito S, Uemura Y, Shibata T, Kondo M, Izumi K, TeradaHirashima J, Mikami A, Sugiura W and Ohmagari N: Clinical epidemiology of hospitalized patients with COVID-19 in Japan: Report of the COVID-19 registry Japan. Clin Infect Dis: 2020. PMID: 32986793. DOI: 10.1093/cid/ciaa1470

4 Liang W, Guan W, Chen R, Wang W, Li J, Xu K, Li C, Ai Q, Lu W, Liang H, Li S and He J: Cancer patients in SARS-CoV-2 infection: A nationwide analysis in China. Lancet Oncol 21(3): 335-337, 2020. PMID: 32066541. DOI: 10.1016/S14702045(20)30096-6

5 Lippi G and Henry BM: Chronic obstructive pulmonary disease is associated with severe coronavirus disease 2019 (COVID-19). Respir Med 167: 105941, 2020. PMID: 32421537. DOI: 10.1016/j.rmed.2020.105941

6 Myers LC, Parodi SM, Escobar GJ and Liu VX: Characteristics of hospitalized adults with COVID-19 in an integrated health care system in California. JAMA 323(21): 2195-2198, 2020. PMID: 32329797. DOI: 10.1001/jama.2020.7202

7 Fadini GP, Morieri ML, Longato E and Avogaro A: Prevalence and impact of diabetes among people infected with SARS-CoV2. J Endocrinol Invest 43(6): 867-869, 2020. PMID: 32222956. DOI: $10.1007 / \mathrm{s} 40618-020-01236-2$

8 Zheng Z, Peng F, Xu B, Zhao J, Liu H, Peng J, Li Q, Jiang C, Zhou Y, Liu S, Ye C, Zhang P, Xing Y, Guo H and Tang W: Risk factors of critical \& mortal COVID-19 cases: A systematic literature review and meta-analysis. J Infect 81(2): e16-e25, 2020. PMID: 32335169. DOI: 10.1016/j.jinf.2020.04.021
9 Popkin BM, Du S, Green WD, Beck MA, Algaith T, Herbst CH, Alsukait RF, Alluhidan M, Alazemi N and Shekar M: Individuals with obesity and COVID-19: A global perspective on the epidemiology and biological relationships. Obes Rev 21(11): e13128, 2020. PMID: 32845580. DOI: 10.1111/obr.13128

10 Latif F, Farr MA, Clerkin KJ, Habal MV, Takeda K, Naka Y, Restaino S, Sayer G and Uriel N: Characteristics and outcomes of recipients of heart transplant with coronavirus disease 2019. JAMA Cardiol: 2020. PMID: 32402056. DOI: 10.1001/ jamacardio.2020.2159

11 Yang J, Zheng Y, Gou X, Pu K, Chen Z, Guo Q, Ji R, Wang H, Wang Y and Zhou Y: Prevalence of comorbidities and its effects in patients infected with SARS-CoV-2: A systematic review and meta-analysis. Int $\mathrm{J}$ Infect Dis 94: 91-95, 2020. PMID: 32173574. DOI: $10.1016 /$ j.ijid.2020.03.017

12 Brenner EJ, Ungaro RC, Gearry RB, Kaplan GG, Kissous-Hunt M, Lewis JD, Ng SC, Rahier JF, Reinisch W, Ruemmele FM, Steinwurz F, Underwood FE, Zhang X, Colombel JF and Kappelman MD: Corticosteroids, but not TNF antagonists, are associated with adverse COVID-19 outcomes in patients with inflammatory bowel diseases: Results from an international registry. Gastroenterology 159(2): 481-491.e3, 2020. PMID: 32425234. DOI: 10.1053/j.gastro.2020.05.032

13 Michelena X, Borrell H, López-Corbeto M, López-Lasanta M, Moreno E, Pascual-Pastor M, Erra A, Serrat M, Espartal E, Antón S, Añez GA, Caparrós-Ruiz R, Pluma A, Trallero-Araguás E, Barceló-Bru M, Almirall M, De Agustín JJ, Lladós J, Julià A and Marsal S: Incidence of COVID-19 in a cohort of adult and paediatric patients with rheumatic diseases treated with targeted biologic and synthetic disease-modifying anti-rheumatic drugs. Semin Arthritis Rheum 50(4): 564-570, 2020. PMID: 32425260. DOI: $10.1016 /$ j.semarthrit.2020.05.001

14 Hadi YB, Naqvi SFZ, Kupec JT and Sarwari AR: Characteristics and outcomes of COVID-19 in patients with HIV: A multicentre research network study. AIDS 34(13): F3-F8, 2020. PMID: 32796217. DOI: $10.1097 / \mathrm{QAD} .0000000000002666$

15 Ellington S, Strid P, Tong VT, Woodworth K, Galang RR, Zambrano LD, Nahabedian J, Anderson K and Gilboa SM: Characteristics of women of reproductive age with laboratory-confirmed SARS-CoV2 infection by pregnancy status - United States, January 22-June 7, 2020. MMWR Morb Mortal Wkly Rep 69(25): 769-775, 2020. PMID: 32584795. DOI: 10.15585/mmwr.mm6925a1

16 Okubo K, Kurono Y, Ichimura K, Enomoto T, Okamoto Y, Kawauchi H, Suzaki H, Fujieda S, Masuyama K and Japanese Society of Allergology: Japanese guidelines for allergic rhinitis 2020. Allergol Int 69(3): 331-345, 2020. PMID: 32473790. DOI: 10.1016/j.alit.2020.04.001

17 Zhou P, Yang XL, Wang XG, Hu B, Zhang L, Zhang W, Si HR, Zhu Y, Li B, Huang CL, Chen HD, Chen J, Luo Y, Guo H, Jiang RD, Liu MQ, Chen Y, Shen XR, Wang X, Zheng XS, Zhao K, Chen QJ, Deng F, Liu LL, Yan B, Zhan FX, Wang YY, Xiao GF and Shi ZL: A pneumonia outbreak associated with a new coronavirus of probable bat origin. Nature 579(7798): 270-273, 2020. PMID: 32015507. DOI: 10.1038/s41586-020-2012-7

18 Hoffmann M, Kleine-Weber H, Schroeder S, Krüger N, Herrler T, Erichsen S, Schiergens TS, Herrler G, Wu NH, Nitsche A, Müller MA, Drosten C and Pöhlmann S: SARS-CoV-2 cell entry depends on ACE2 and TMPRSS2 and is blocked by a clinically proven protease inhibitor. Cell 181(2): 271-280.e8, 2020. PMID: 32142651. DOI: $10.1016 /$ j.cell.2020.02.052 
19 Walls AC, Park YJ, Tortorici MA, Wall A, McGuire AT and Veesler D: Structure, function, and antigenicity of the SARSCoV-2 spike glycoprotein. Cell 181(2): 281-292.e6, 2020. PMID: 32155444. DOI: 10.1016/j.cell.2020.02.058

20 Lehrer S and Rheinstein PH: Ivermectin docks to the SARSCoV-2 spike receptor-binding domain attached to ACE2. In Vivo 34(5): 3023-3026, 2020. PMID: 32871846. DOI: 10.21873/ invivo. 12134

21 Bertram S, Heurich A, Lavender H, Gierer S, Danisch S, Perin P, Lucas JM, Nelson PS, Pöhlmann S and Soilleux EJ: Influenza and SARS-coronavirus activating proteases TMPRSS2 and HAT are expressed at multiple sites in human respiratory and gastrointestinal tracts. PLoS One 7(4): e35876, 2012. PMID: 22558251. DOI: 10.1371/journal.pone.0035876

22 Sungnak W, Huang N, Bécavin C, Berg M, Queen R, Litvinukova M, Talavera-López C, Maatz H, Reichart D, Sampaziotis F, Worlock KB, Yoshida M, Barnes JL and HCA Lung Biological Network: SARS-CoV-2 entry factors are highly expressed in nasal epithelial cells together with innate immune genes. Nat Med 26(5): 681-687, 2020. PMID: 32327758. DOI: 10.1038/s41591-020-0868-6

23 Ziegler CGK, Allon SJ, Nyquist SK, Mbano IM, Miao VN, Tzouanas CN, Cao Y, Yousif AS, Bals J, Hauser BM, Feldman J, Muus C, Wadsworth MH 2nd, Kazer SW, Hughes TK, Doran B, Gatter GJ, Vukovic M, Taliaferro F, Mead BE, Guo Z, Wang JP, Gras D, Plaisant M, Ansari M, Angelidis I, Adler H, Sucre JMS, Taylor CJ, Lin B, Waghray A, Mitsialis V, Dwyer DF, Buchheit KM, Boyce JA, Barrett NA, Laidlaw TM, Carroll SL, Colonna L, Tkachev V, Peterson CW, Yu A, Zheng HB, Gideon HP, Winchell CG, Lin PL, Bingle CD, Snapper SB, Kropski JA, Theis FJ, Schiller HB, Zaragosi LE, Barbry P, Leslie A, Kiem HP, Flynn JL, Fortune SM, Berger B, Finberg RW, Kean LS, Garber M, Schmidt AG, Lingwood D, Shalek AK, OrdovasMontanes J, and HCA Lung Biological Network: SARS-CoV-2 receptor ACE2 is an interferon-stimulated gene in human airway epithelial cells and is detected in specific cell subsets across tissues. Cell 181(5): 1016-1035.e19, 2020. PMID: 32413319. DOI: 10.1016/j.cell.2020.04.035

24 Sajuthi SP, DeFord P, Li Y, Jackson ND, Montgomery MT, Everman JL, Rios CL, Pruesse E, Nolin JD, Plender EG, Wechsler ME, Mak ACY, Eng C, Salazar S, Medina V, Wohlford EM, Huntsman S, Nickerson DA, Germer S, Zody MC, Abecasis G, Kang HM, Rice KM, Kumar R, Oh S, Rodriguez-Santana J, Burchard EG and Seibold MA: Type 2 and interferon inflammation regulate SARS-CoV-2 entry factor expression in the airway epithelium. Nat Commun 11(1): 5139, 2020. PMID: 33046696. DOI: $10.1038 / \mathrm{s} 41467-020-18781-2$

25 Smith JC, Sausville EL, Girish V, Yuan ML, Vasudevan A, John KM and Sheltzer JM: Cigarette smoke exposure and inflammatory signaling increase the expression of the SARSCoV-2 receptor ACE2 in the respiratory tract. Dev Cell 53(5): 514-529.e3, 2020. PMID: 32425701. DOI: 10.1016/j.devcel. 2020.05 .012

26 Radzikowska U, Ding M, Tan G, Zhakparov D, Peng Y, Wawrzyniak P, Wang M, Li S, Morita H, Altunbulakli C, Reiger M, Neumann AU, Lunjani N, Traidl-Hoffmann C, Nadeau KC, O'Mahony L, Akdis C and Sokolowska M: Distribution of ACE2, CD147, CD26, and other SARS-CoV-2 associated molecules in tissues and immune cells in health and in asthma, COPD, obesity, hypertension, and COVID-19 risk factors.
Allergy 75(11): 2829-2845, 2020. PMID: 32496587. DOI: 10.1111/all.14429

27 Hamming I, Cooper ME, Haagmans BL, Hooper NM, Korstanje $\mathrm{R}$, Osterhaus AD, Timens W, Turner AJ, Navis G and van Goor $\mathrm{H}$ : The emerging role of ACE2 in physiology and disease. $J$ Pathol 212(1): 1-11, 2007. PMID: 17464936. DOI: 10.1002/ path.2162

28 Wösten-van Asperen RM, Lutter R, Specht PA, Moll GN, van Woensel JB, van der Loos CM, van Goor H, Kamilic J, Florquin $\mathrm{S}$ and Bos AP: Acute respiratory distress syndrome leads to reduced ratio of ACE/ACE2 activities and is prevented by angiotensin-(1-7) or an angiotensin II receptor antagonist. J Pathol 225(4): 618-627, 2011. PMID: 22009550. DOI: 10.1002/path.2987

29 Magalhães GS, Rodrigues-Machado MG, Motta-Santos D, Silva AR, Caliari MV, Prata LO, Abreu SC, Rocco PR, Barcelos LS, Santos RA and Campagnole-Santos MJ: Angiotensin-(1-7) attenuates airway remodelling and hyperresponsiveness in a model of chronic allergic lung inflammation. Br J Pharmacol 172(9): 2330-2342, 2015. PMID: 25559763. DOI: 10.1111/ bph.13057

30 Zou L, Ruan F, Huang M, Liang L, Huang H, Hong Z, Yu J, Kang M, Song Y, Xia J, Guo Q, Song T, He J, Yen HL, Peiris $\mathrm{M}$ and $\mathrm{Wu} \mathrm{J}$ : SARS-CoV-2 viral load in upper respiratory specimens of infected patients. N Engl J Med 382(12): 11771179, 2020. PMID: 32074444. DOI: 10.1056/NEJMc2001737

31 Vaira LA, Salzano G, Deiana G and De Riu G: Anosmia and ageusia: Common findings in COVID-19 patients. Laryngoscope 130(7): 1787, 2020. PMID: 32237238. DOI: 10.1002/lary.28692

32 Giacomelli A, Pezzati L, Conti F, Bernacchia D, Siano M, Oreni L, Rusconi S, Gervasoni C, Ridolfo AL, Rizzardini G, Antinori S and Galli M: Self-reported olfactory and taste disorders in patients with severe acute respiratory coronavirus 2 infection: A cross-sectional study. Clin Infect Dis 71(15): 889-890, 2020. PMID: 32215618. DOI: 10.1093/cid/ciaa330

33 Yan CH, Faraji F, Prajapati DP, Boone CE and DeConde AS: Association of chemosensory dysfunction and COVID-19 in patients presenting with influenza-like symptoms. Int Forum Allergy Rhinol 10(7): 806-813, 2020. PMID: 32279441. DOI: 10.1002/alr.22579

34 Lechien JR, Chiesa-Estomba CM, De Siati DR, Horoi M, Le Bon SD, Rodriguez A, Dequanter D, Blecic S, El Afia F, Distinguin L, Chekkoury-Idrissi Y, Hans S, Delgado IL, CalvoHenriquez C, Lavigne P, Falanga C, Barillari MR, Cammaroto G, Khalife M, Leich P, Souchay C, Rossi C, Journe F, Hsieh J, Edjlali M, Carlier R, Ris L, Lovato A, De Filippis C, Coppee F, Fakhry N, Ayad T and Saussez S: Olfactory and gustatory dysfunctions as a clinical presentation of mild-to-moderate forms of the coronavirus disease (COVID-19): A multicenter European study. Eur Arch Otorhinolaryngol 277(8): 2251-2261, 2020. PMID: 32253535. DOI: 10.1007/s00405-020-05965-1

35 Mao L, Jin H, Wang M, Hu Y, Chen S, He Q, Chang J, Hong C, Zhou Y, Wang D, Miao X, Li Y and $\mathrm{Hu}$ B: neurologic manifestations of hospitalized patients with coronavirus disease 2019 in Wuhan, China. JAMA Neurol 77(6): 683-690, 2020. PMID: 32275288. DOI: 10.1001/jamaneurol.2020.1127

36 Hopkins C, Surda P, Whitehead E and Kumar BN: Early recovery following new onset anosmia during the COVID-19 pandemic - an observational cohort study. J Otolaryngol Head Neck Surg 49(1): 26, 2020. PMID: 32366299. DOI: 10.1186/ s40463-020-00423-8 
37 Chiesa-Estomba CM, Lechien JR, Radulesco T, Michel J, Sowerby LJ, Hopkins C and Saussez S: Patterns of smell recovery in 751 patients affected by the COVID-19 outbreak. Eur J Neurol 27(11): 2318-2321, 2020. PMID: 32677329. DOI: 10.1111/ene. 14440

38 Eliezer M, Hautefort C, Hamel AL, Verillaud B, Herman P, Houdart E and Eloit C: Sudden and complete olfactory loss of function as a possible symptom of COVID-19. Jama Otolaryngol Head Neck Surg 146(7): 674-675, 2020. PMID: 32267483. DOI: 10.1001/jamaoto.2020.0832

39 Brann DH, Tsukahara T, Weinreb C, Lipovsek M, Van den Berge K, Gong B, Chance R, Macaulay IC, Chou HJ, Fletcher RB, Das D, Street K, de Bezieux HR, Choi YG, Risso D, Dudoit S, Purdom E, Mill J, Hachem RA, Matsunami H, Logan DW, Goldstein BJ, Grubb MS, Ngai J and Datta SR: Non-neuronal expression of SARS-CoV-2 entry genes in the olfactory system suggests mechanisms underlying COVID-19-associated anosmia. Sci Adv 6(31): 2020. PMID: 32937591. DOI: 10.1126/sciadv. abc5801

40 Bilinska K, Jakubowska P, Von Bartheld CS and Butowt R: Expression of the SARS-CoV-2 entry proteins, ACE2 and TMPRSS2, in cells of the olfactory epithelium: Identification of cell types and trends with age. ACS Chem Neurosci 11(11): 1555-1562, 2020. PMID: 32379417. DOI: 10.1021/ acschemneuro.0c00210

41 Bryche B, St Albin A, Murri S, Lacôte S, Pulido C, Ar Gouilh M, Lesellier S, Servat A, Wasniewski M, Picard-Meyer E, Monchatre-Leroy E, Volmer R, Rampin O, Le Goffic R, Marianneau P and Meunier N: Massive transient damage of the olfactory epithelium associated with infection of sustentacular cells by SARS-CoV-2 in golden Syrian hamsters. Brain Behav Immun 89: 579-586, 2020. PMID: 32629042. DOI: 10.1016/ j.bbi.2020.06.032

$42 \mathrm{Wu} \mathrm{Z}$ and McGoogan JM: Characteristics of and important lessons from the coronavirus disease 2019 (COVID-19) outbreak in China: Summary of a report of 72314 cases from the Chinese center for disease control and prevention. JAMA 323(13): 1239-1242, 2020. PMID: 32091533. DOI: 10.1001/jama.2020.2648

43 Pfaar O, Klimek L, Jutel M, Akdis CA, Bousquet J, Breiteneder H, Chinthrajah S, Diamant Z, Eiwegger T, Fokkens WJ, Fritsch HW, Nadeau KC, O'Hehir RE, O’Mahony L, Rief W, Sampath V, Schedlowski M, Torres MJ, Traidl-Hoffmann C, Wang Y, Zhang L, Bonini M, Brehler R, Brough HA, Chivato T, Del Giacco SR, Dramburg S, Gawlik R, Gelincik A, HoffmannSommergruber K, Hox V, Knol EF, Lauerma A, Matricardi PM, Mortz CG, Ollert M, Palomares O, Riggioni C, Schwarze J, Skypala I, Untersmayr E, Walusiak-Skorupa J, Ansotegui IJ, Bachert C, Bedbrook A, Bosnic-Anticevich S, Brussino L, Canonica GW, Cardona V, Carreiro-Martins P, Cruz AA, Czarlewski W, Fonseca JA, Gotua M, Haahtela T, Ivancevich JC, Kuna P, Kvedariene V, Larenas-Linnemann DE, Abdul Latiff AH, Mäkelä M, Morais-Almeida M, Mullol J, Naclerio R, Ohta K, Okamoto Y, Onorato GL, Papadopoulos NG, Patella V, Regateiro FS, Samoliński B, Suppli Ulrik C, Toppila-Salmi S, Valiulis A, Ventura MT, Yorgancioglu A, Zuberbier T and Agache I: COVID-19 pandemic: Practical considerations on the organization of an allergy clinic-An EAACI/ARIA position paper. Allergy 76(3): 648-676, 2021. PMID: 32531110. DOI: $10.1111 /$ all.14453
44 Kimura H, Francisco D, Conway M, Martinez F, Vercelli D, Polverino F, Billheimer D and Kraft M: Type 2 inflammation modulates ACE2 and TMPRSS2 in airway epithelial cells. Journal of Allergy and Clinical Immunology 146(1): 80-88.e8, 2021. DOI: $10.1016 /$ j.jaci.2020.05.004

45 Jackson DJ, Busse WW, Bacharier LB, Kattan M, O'Connor GT, Wood RA, Visness CM, Durham SR, Larson D, Esnault S, Ober C, Gergen PJ, Becker P, Togias A, Gern JE and Altman MC: Association of respiratory allergy, asthma, and expression of the SARS-CoV-2 receptor ACE2. J Allergy Clin Immunol 146(1): 203206.e3, 2020. PMID: 32333915. DOI: 10.1016/j.jaci.2020.04.009

46 Zhang JJ, Dong X, Cao YY, Yuan YD, Yang YB, Yan YQ, Akdis CA and Gao YD: Clinical characteristics of 140 patients infected with SARS-CoV-2 in Wuhan, China. Allergy 75(7): 1730-1741, 2020. PMID: 32077115. DOI: 10.1111/all.14238

47 Bousquet J, Akdis C, Jutel M, Bachert C, Klimek L, Agache I, Ansotegui IJ, Bedbrook A, Bosnic-Anticevich S, Canonica GW, Chivato T, Cruz AA, Czarlewski W, Del Giacco S, Du H, Fonseca JA, Gao Y, Haahtela T, Hoffmann-Sommergruber K, Ivancevich JC, Khaltaev N, Knol EF, Kuna P, LarenasLinnemann D, Mullol J, Naclerio R, Ohta K, Okamoto Y, O'Mahony L, Onorato GL, Papadopoulos NG, Pfaar O, Samolinski B, Schwarze J, Toppila-Salmi S, Teresa Ventura M, Valiulis A, Yorgancioglu A, Zuberbier T and ARIA-MASK Study Group: Intranasal corticosteroids in allergic rhinitis in COVID-19 infected patients: An ARIA-EAACI statement. Allergy: 2020. PMID: 32233040. DOI: 10.1111/all.14302

48 Klimek L, Jutel M, Akdis C, Bousquet J, Akdis M, Bachert C, Agache I, Ansotegui I, Bedbrook A, Bosnic-Anticevich S, Canonica GW, Chivato T, Cruz AA, Czarlewski W, Del Giacco S, Du H, Fonseca JA, Gao Y, Haahtela T, HoffmannSommergruber K, Ivancevich JC, Khaltaev N, Knol EF, Kuna P, Larenas-Linnemann D, Melen E, Mullol J, Naclerio R, Ohta K, Okamoto Y, O’Mahony L, Onorato GL, Papadopoulos NG, Pawankar R, Pfaar O, Samolinski B, Schwarze J, Toppila-Salmi S, Shamji MH, Teresa Ventura M, Valiulis A, Yorgancioglu A, Matricardi P, Zuberbier T and ARIA-MASK Study Group: Handling of allergen immunotherapy in the COVID-19 pandemic: An ARIA-EAACI statement. Allergy 75(7): 15461554, 2020. PMID: 32329930. DOI: 10.1111/all.14336

49 Okubo K, Okano M, Sato N, Tamaki Y, Suzuki H, Uddin A and Fogel R: Add-on omalizumab for inadequately controlled severe pollinosis despite standard-of-care: A randomized study. J Allergy Clin Immunol Pract 8(9): 3130-3140.e2, 2020. PMID: 32422373. DOI: 10.1016/j.jaip.2020.04.068

50 Grayson JW, Hopkins C, Mori E, Senior B and Harvey RJ: Contemporary classification of chronic rhinosinusitis beyond polyps vs. no polyps: A review. JAMA Otolaryngol Head Neck Surg 146(9): 831-838, 2020. PMID: 32644117. DOI: 10.1001/ jamaoto.2020.1453

51 Tokunaga T, Sakashita M, Haruna T, Asaka D, Takeno S, Ikeda H, Nakayama T, Seki N, Ito S, Murata J, Sakuma Y, Yoshida N, Terada T, Morikura I, Sakaida H, Kondo K, Teraguchi K, Okano M, Otori N, Yoshikawa M, Hirakawa K, Haruna S, Himi T, Ikeda K, Ishitoya J, Ino Y, Kawata R, Kawauchi H, Kobayashi M, Yamasoba T, Miwa T, Urashima M, Tamari M, Noguchi E, Ninomiya T, Imoto Y, Morikawa T, Tomita K, Takabayashi T and Fujieda S: Novel scoring system and algorithm for classifying chronic rhinosinusitis:The JESREC study. Allergy 70(8): 9951003, 2015. PMID: 25945591. DOI: 10.1111/all.12644 
52 Fujieda S, Imoto $\mathrm{Y}$, Kato $\mathrm{Y}$, Ninomiya $\mathrm{T}$, Tokunaga $\mathrm{T}$, Tsutsumiuchi T, Yoshida K, Kidoguchi M and Takabayashi T: Eosinophilic chronic rhinosinusitis. Allergol Int 68(4): 403-412, 2019. PMID: 31402319. DOI: 10.1016/j.alit.2019.07.002

53 Chhiba KD, Patel GB, Vu THT, Chen MM, Guo A, Kudlaty E, Mai Q, Yeh C, Muhammad LN, Harris KE, Bochner BS, Grammer LC, Greenberger PA, Kalhan R, Kuang FL, Saltoun CA, Schleimer RP, Stevens WW and Peters AT: Prevalence and characterization of asthma in hospitalized and nonhospitalized patients with COVID-19. J Allergy Clin Immunol 146(2): 307314.e4, 2020. PMID: 32554082. DOI: 10.1016/j.jaci.2020.06.010

54 Yao Y, Wang H and Liu Z: Expression of ACE2 in airways: Implication for COVID-19 risk and disease management in patients with chronic inflammatory respiratory diseases. Clin Exp Allergy 50(12): 1313-1324, 2020. PMID: 32975865. DOI: $10.1111 /$ cea. 13746

55 Global initiative for asthma. Interim guidance about COVID-19 and asthma. Available at: https://ginasthma.org/wp-content/ uploads/2020/12/GINA-interim-guidance-on-COVID-19-andasthma-20_12_20.pdf [Last accessed on March 23, 2021]

Received February 23, 2021

Revised March 11, 2021

Accepted March 23, 2021 